Dmitriy E. Andrianov1, Sergey V. Eremeev², Yuri A. Kovalev ${ }^{3} \quad$ DOI: 10.25045/jpit.v10.i2.02 Murom institute (branch) of the state educational institution of the higher vocational training «Vladimir state university», Murom, Russia

1andrianovde@inbox.ru, ${ }^{2}$ sv-eremeev@yandex.ru, ${ }^{3}$ yurko02@mail.ru

\title{
ALGORITHM FOR ANALYSIS OF SPATIAL SCENES ND-OBJECTS IN GEOINFORMATION SYSTEMS
}

\author{
Received: 21.12.2018 Revised: 27.02.2019 Accepted: 10.03.2019
}

The article developed an algorithm that allows analyzing nd-objects at different time intervals and at different scales. The algorithm of analysis of spatial scenes allows you to see the topological relationship between objects. Unlike geometric, topological characteristics do not depend on the location of objects. The algorithm is based on computer topology methods using the Cech complex. As a result of the implementation of the algorithm, barcodes of spatial objects are cited and analyzed.

Keywords: spatial object classification, topology, geoinformatics, Barcode.

\section{Introduction}

Currently, the construction of geographic information systems (GIS) is increasingly used vector maps. The main parts that make up the vector model are geometric objects, attributes, and topological characteristics.

The following algorithms and methods are widely used for solving problems of analyzing changes in spatial objects:

1. An algorithm for processing spatial data based on a shiarlet transform. The shiarlet transform is a data transform that includes a shift and a parallel transfer operator. This wavelet transform has a parallel transfer in time, and also scales in frequency. In addition, it includes the directional characteristic with the shift operation in addition.

In the diagnosis of complex geoecological objects and systems for identifying singularities (curvilinear features), as well as in assessing the territorial risks of natural and man-made nature, this type of data conversion will allow to obtain a new geometric interpretation in the processing of space-time series and images. Thus, the shear transformation takes into account the properties of the medium under study, but the mathematical apparatus for analyzing complex spatial data is the same for different models. Shiarlet-transformation is well applicable for fixing the regularity of the image in complex environments, takes into account the scale, space and direction [1].

2. A method based on the relationship of adjacency and inclusion between areas defined by sets of contours. The method retrieves the features of the landscape and stores them in the tree of features, providing a description of the landscape at several levels of detail.

This method can be applied to the generalization of the contour map and analysis of the terrain. To do this, select the most relevant functions in accordance with the purpose of the map. Contouring lines are important for determining morphological features on the map and quantitatively display the relief. Contour trees are used to represent the spatial relationships between the contours. It helps in analyzing the landscape. However, since the functions indicated on the map by sets of contours are characterized by local relations between them and relations with other elements at different levels of representation, automatic analysis is still limited [2].

The main disadvantage of these algorithms is their dependence on the geometric characteristics, including the coordinates of objects. This significantly increases the running time of the algorithm, as well as the amount of data that needs to be stored.

The actual task both at the world and at the Russian level is the analysis of data on maps with different scales and the analysis of tracking the evolution of objects in time [3-7]. In this paper, the analysis of $\mathrm{nD}$ objects will be made on the basis of their topological features that 
reflect the overall structure of the object. Data that is stored and processed in a single $\mathrm{n}$ - dimensional space is called $\mathrm{nD}$ objects. These objects are based on $\mathrm{n}$-dimensional simplexes. Formulation of the problem

The paper sets the task of implementing an algorithm for analyzing spatial scenes in $\mathrm{n}$ dimensional space. This algorithm should analyze spatial data at different scales and at different time intervals. The main advantage of the algorithm is to work with a group of spatial objects as a whole, which will allow to:

1. Use the topological characteristics of the object.

2. Analyze a group of objects, regardless of scale.

\section{Development of an algorithm for analyzing spatial scenes with nD objects in geographic information systems}

In our work, the Cech complex is used to search for differences in spatial objects. This is the theory of algebraic topology, which is based on the properties of topological spaces. This algorithm is useful in case of detection of changes in spatial objects. In algebraic topology and analysis of topological data, the Cech complex is an abstract simplicial complex constructed from a cloud of points in any topological space designed to capture topological information about circles around points or the distribution from which it was made $[8,9]$.

On the basis of this simplicial complex, a Barcode $B$ is constructed, containing the topological characteristics of the object.

The main feature of the algorithm is that the Barcode is built not for a single object, but for the whole group. This allows you to significantly reduce the time to access objects and get a general description of a group of objects. It also allows you to store information for objects at different scales.

Let's assume that $X_{1} X_{2}, \ldots, X_{n}$ are the spatial objects consisting of sequences of points ( $n$ - the number of objects).

Then $B\left(X_{1}, X_{2}, \ldots, X_{n}\right)=\left\{\left(x_{i}, l_{i}\right)\right\}$, where $(i=1,2, \ldots, m)$ is the Barcode of a group of objects, which is a set of topological characteristics. In the work, as a topological characteristic, holes are used that are formed during the formation of a simplicial complex. At the same time $x_{i}$ - the coordinate of the beginning of the life of the hole, $l_{i}$ - the lifetime of the hole, $m$ - the number of holes.

Based on the Barcodes, $\mathrm{nD}$ objects are analyzed on the vector maps shown in figure 1 (a, $b, c)$ and the result of this analysis is displayed in the form of Barcode charts in figure 1 $(\mathrm{d}, \mathrm{e}, \mathrm{f})$.

The Barcode analysis is performed by overlaying them on each other and finding their differences. Using this algorithm, it can be understood that the Barcode is built on the basis of similar groups of objects, and also to analyze how many objects were changed.

Based on the graphs in figure $1(\mathrm{~d}, \mathrm{e}, \mathrm{f})$, we can conclude that the structure of objects is similar to Barcode, but there are also changes that allow you to visually determine the differences between objects.

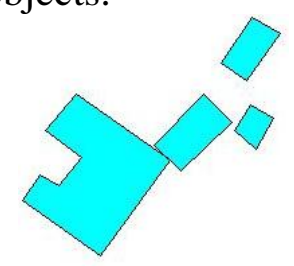

a)

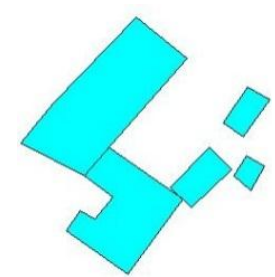

b)

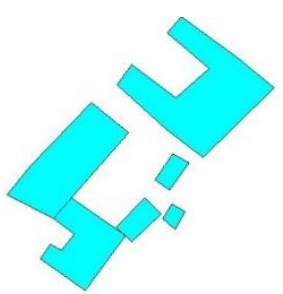

c) 


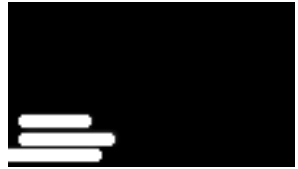

d)

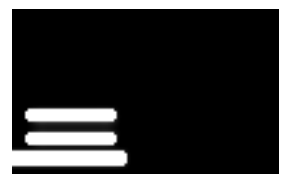

e)

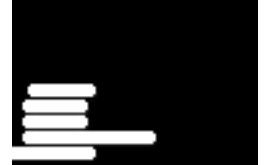

f)

Figure 1. Source objects and the corresponding Barcode: a-c) - Objects changed in time;

d-f) - Barcodes of objects modified in time

\section{Conducting an experiment}

\section{Analysis of Barcodes of groups of objects at different scales.}

Consider the change of Barcodes of groups of objects on a real example. In figure 2 (a, c) the set of objects and their Barcode are displayed, respectively, on a scale of 1:50, and in figure 2 (b, d), a group of objects is shown on a scale of 1:20. Performance of the experiment.

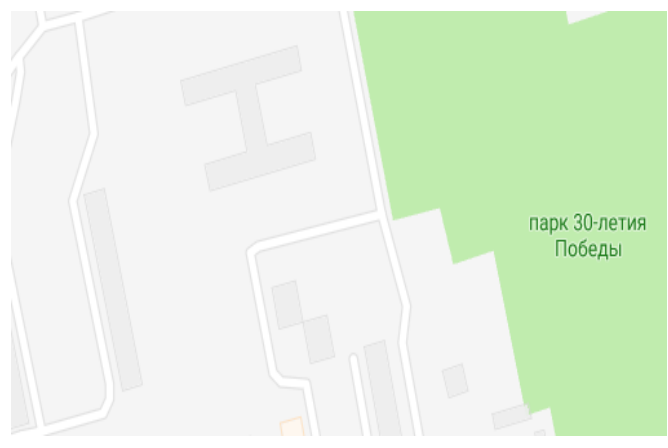

a)

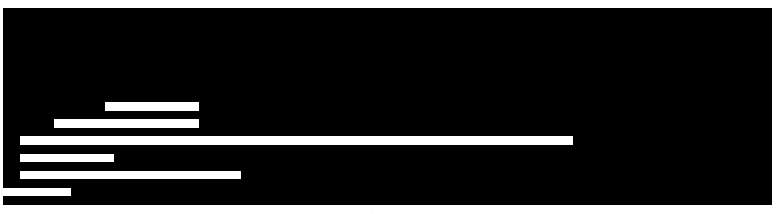

c)

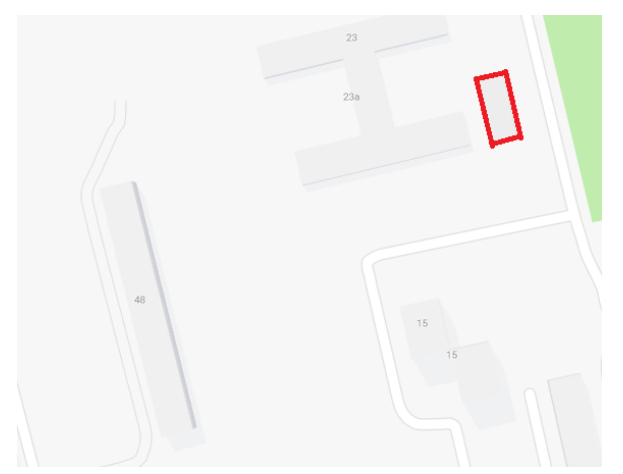

b)

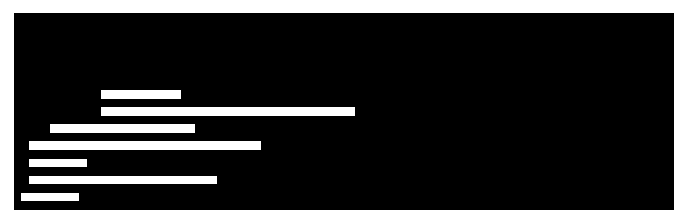

d)

Figure 2. A group of objects and their corresponding barcodes: a-b) Objects on two different scales; c-d) - Barcodes of objects on two scales

In figure 2 (b), an object is highlighted in red, which has become visible on a 1:20 scale. After analyzing the Barcodes of figure 2 (c-d), it can be concluded that the Bar Codes have a slight difference that indicates the presence of an object on a different scale.

\section{Analysis of Barcodes of groups of objects at different time intervals}

To carry out this experiment in the environment of GIS INGEO, a group of objects was restored from the tablets of the city of Murom for 1990. For 2018, information about this area was taken from Yandex maps. Comparisons of these groups of objects and their Barcodes are shown in figure 3. 


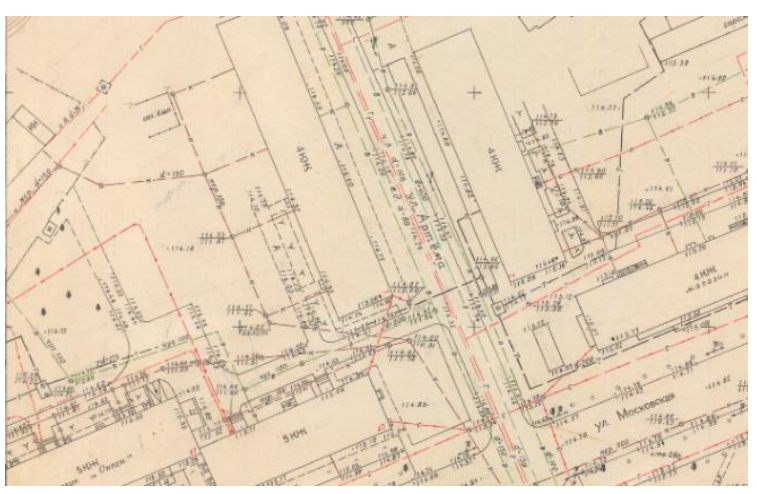

a)

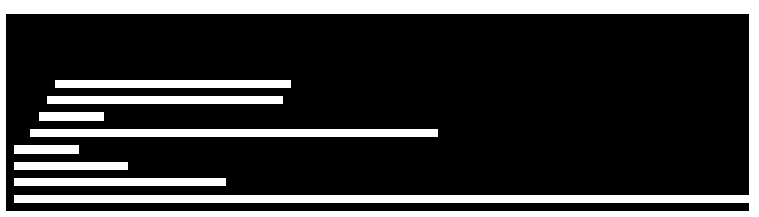

c)

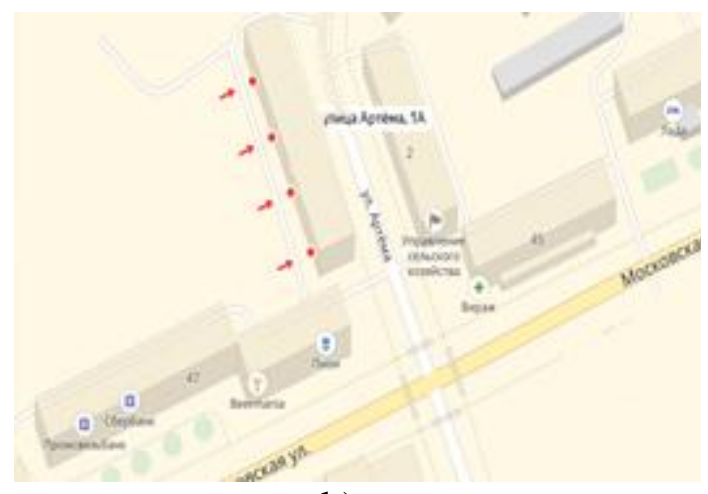

b)

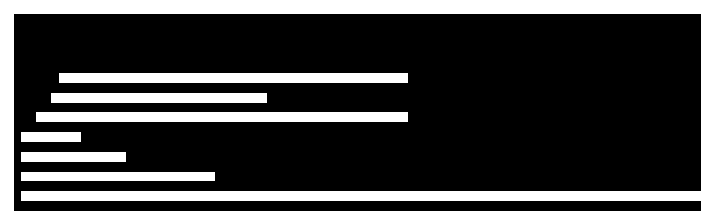

d)

Figure 3. The group of objects and their Barcodes: $a-b)$ - Objects that change over time; c-d) - Barcodes of objects at different time intervals

Figure $3(a, b)$ shows minor differences in the form of small parts (entrances, extensions, etc.), although the buildings themselves are identical. The bar codes of these groups of objects in figure $3(\mathrm{c}, \mathrm{d})$ reflect the differences in the maps in the upper part of the graphs, and in the lower part it is clear that the houses themselves remained unchanged.

\section{Discussion of the results and conclusion}

The article developed an algorithm for analyzing spatial scenes at different scales and at different time intervals. Algorithms analogs from foreign literature are analyzed, as well as test and real experiments of the algorithm are carried out.

Analysis of time evolution will be useful in construction in the design of buildings, utilities, agriculture. It allows you to calculate the labor costs for building new areas, tracking the modification of buildings in time and planning their construction.

\section{Acknowledgments}

The study was carried out with the financial support of the Russian Foundation for Basic Research and the Administration of the Vladimir Region in the framework of the research project No. 17-47-330387.

\section{References}

1. Simonov K., Kadena L. Algorithm of processing spatial data based on shiarlet-transformation // Processing of spatial data and remote monitoring of the natural environment and large-scale anthropogenic processes, 2013, pp.100-114.

2. Guilbert E. Multi-level representation of terrain features on a contour map // Geoinformatica, 2013, vol.17, pp.301-324.

3. Zhilin Li, Qi Zhou. Integration of linear and areal hierarchies for continuous multi-scale representation of road networks // International Journal of Geographical Information Science, 2012, vol.26. pp.855-880.

4. Herbei I. Radulov. Topology of spatial data / The Proceedings 15th International Multidisciplinary Scientific GeoConference (SGEM 2015), 2015, Book 2, vol.2, 2015, pp.87-94. 
5. Fedoseev V.A., Chupshev N.V. Investigation of methods for detecting anthropogenic changes on the earth's surface using a sequence of high-resolution satellite images Computer optics, 2012, vol.36 no.2, pp.279-288.

6. Arroyo Ohori K., Ledoux H. and Stoter J., A dimensionin dependent extrusion algorithm using generalized maps // International Journal of Geographical Information Science, vol. 29, no 7, pp.1166-1186.

7. Shyam Boriah. Time series change detection: algorithms for land cover change. A dissertation submitted to the faculty of the graduate school of the university of Minnesota, 2010, $146 \mathrm{p}$.

8. Jean-Daniel Boissonnat, Karthik C. Srikanta, Sébastien Tavenas. Building Efficient and Compact Data Structures for Simplicial Complexes // Algorithmica. An Extended Abstract, 2015, pp. 530-567.

9. Edelsbrunner H. and M"ucke E.P.: Three-dimensional alpha shapes. ACM Transactions on Graphics, vol.13, 1994, pp.43-72.

\section{UOT 621.397.01}

\section{Andrianov Dmitriy Y. ${ }^{1}$, Yeremeyev Sergey V. ${ }^{2}$, Kovalyov Yuriy A. ${ }^{3}$}

Ali peşə təhsili üzrə dövlət təhsil müəssisəsi "Vladimir Dövlət Universiteti”nin Murom İnstitutu (filialı) Murom, Rusiya 1 andrianovde@inbox.ru, ${ }^{2}$ sv-eremeev@yandex.ru, ${ }^{3}$ yurko02@ mail.ru

\section{Geoinformasiya sistemlərində $\mathrm{nD}$-obyektlərinin məkan səhnələrinin analizi alqoritmi}

Məqalədə $\mathrm{nD}$ obyektlərini müxtəlif zaman kəsimində və müxtəlif miqyaslarda analiz etməyə imkan verən alqoritm işlənmişdir. Məkan səhnələrinin analizi alqoritmi obyektlər arasında topologiya əlaqəsini görməyə imkan verir. Həndəsi xarakteristikalardan fərqli olaraq, topoloji xarakteristika obyektlərin yerləşməsindən asılı deyil. Alqoritmin əsasını Çex kompleksindən istifadə ilə kompüter topologiyası metodları təşkil edir. Alqoritmin reallaşdırılmasının nəticəsi kimi məkan obyektlərinin Barkodu verilir və onların analizi həyata keçirilir.

Açar sözlor: məkan obyektlarinin təsnifatı, topologiya, geoinformatika, Barkod.

\section{УДК 621.397.01}

Андрианов Дмитрий Е. ${ }^{1}$, Еремеев Сергей B. ${ }^{2}$, Ковалев Юрий А. ${ }^{3}$

Муромский институт (филиал) государственного образовательного учреждения высшего профессионального образования «Владимирский государственный университет»

1andrianovde@inbox.ru, ${ }^{2}$ sv-eremeev@yandex.ru, ${ }^{3}$ yurko02@ mail.ru

\section{Алгоритм анализа пространственных сцен $\mathrm{nD-объектов} \mathrm{в} \mathrm{геоинформационных}$ системах}

В статье разработан алгоритм, который позволяет анализировать $\mathrm{nD}$ объекты в разные промежутки времени и на разных масштабах. Алгоритм анализа пространственных сцен позволяет увидеть топологическую связь между объектами. В отличие от геометрических, топологические характеристики не зависят от расположения объектов. Основу алгоритма составляют методы компьютерной топологии с использованием комплекса Чеха. В качестве результата реализации алгоритма приводятся Баркоды пространственных объектов и производится их анализ.

Ключевые слова: классификация пространственных объектов, топология, геоинформатика, Баркод. 